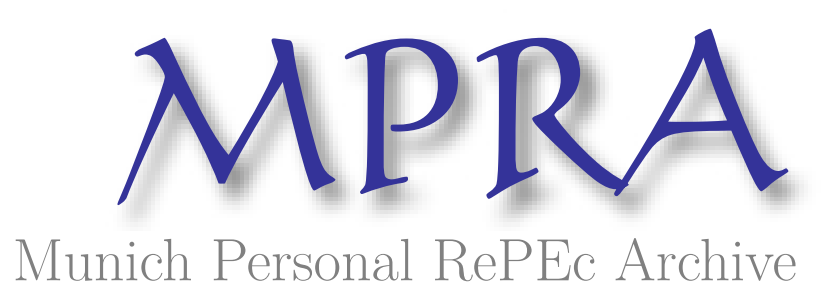

\title{
Public Debt and J.S. Mill's Conjecture: A Note
}

\author{
Tsoulfidis, Lefteris \\ University of Macedonia
}

2 February 2011

Online at https://mpra.ub.uni-muenchen.de/44777/

MPRA Paper No. 44777, posted 06 Mar 2013 13:48 UTC 


\title{
Public Debt and J.S. Mill's Conjecture: A Note
}

\author{
Lefteris Tsoulfidis \\ Associate Professor \\ Department of Economics \\ University of Macedonia \\ 156 Egnatia Street \\ Tel.: $302310891-788$ \\ E-mail: Lnt@uom.gr
}

\begin{abstract}
Classical economists mainly Smith, Ricardo and J.S. Mill abhorred public debts because of their interference with capital accumulation. J.S. Mill in particular envisaged that a rising public debt leads to higher interest rates and falling real wages, a combination which may be consistent with a mildly increasing trend in the profit rate.
\end{abstract}

Key Words: Classical Economists, Public Debt, J.S. Mill, Ricardian Equivalence

JEL Classification Numbers: B12, B13, B14, B16, H50

\section{Introduction}

Classical economists (mainly Smith, Ricardo and J.S. Mill) saw in the rising public debt the growth of unproductive government expenditures and the crowding out of the private savings which diminish society's investible product. This view has been put forward mainly by Smith and was further elaborated by Ricardo. The third of the classical economists, J.S. Mill, contended that an exceptionally rising debt, as this was the case for example in the wars of England with France, leads to rising interest rates as the public competes with the private sector of the economy over the same pool of funds. The subsequent slow down in capital accumulation and the growth of productive employment lead to rising unemployment and the ensuing intensification of competition among workers for jobs reduces their real wage and so the rate of profit may mildly increase.

The purpose of this article is to show that the core ideas of classical economists and especially those of J.S. Mill, on the effects of a rising public debt were justified from the available evidence of the period that the public debt of the UK increased to unprecedented highs. Thus we put together data for the relevant variables for the wars 
infested period beginning with the Seven Years' War (1756-1763) and ending with the Napoleonic Wars (1793-1815). The remainder of the article is organized as follows: section 2 summarizes the views of Smith and Ricardo on the harmful effects of public debt on capital accumulation and having to choose between borrowing and taxation as two alternative methods of financing the government expenditures they opted for taxation. Section 3 presents J.S. Mill's conjecture on public debt and supports it with some empirical findings during the period 1756-1815. Section 4 summarizes and makes some concludes remarks about future research efforts.

\section{Classical Economists on Public Debt}

Adam Smith analyzes the economic effects of public debt mainly in his fifth (and last) book of the Wealth of Nation (pp. 859-900), where he argues that governments should not run budget deficits because these lead to the accumulation of public debt with destructive effects for the nation even if all of it was owed domestically. Hence, Smith takes issue with the widely accepted in his times mercantilist view according to which the payment of interest on public debt is an innocuous redistribution of income within the country - "the right hand which pays the left", kind of argument - and he characterized it as an "apology founded altogether on the sophistry of the mercantile system" (Wealth of Nations, p. 879). Smith based his view on the idea that the redemption of public debt in the future will entail increased taxation with negative effects on the investment potential of domestic producers and also the flight of capital to foreign countries (Wealth of Nations, p. 880). The debt, according to Smith, undermines the "natural progress of a nation towards wealth and prosperity" (Wealth of Nation, p. 638) since resources that could be used productively from the private sector of the economy are diverted by the state in order to finance its unproductive activities. Consequently, Smith's ideal would be balanced budgets, and only under emergency situations (such as wars, natural calamities, and the like) the government perhaps was justified to run budget deficits and accumulate debt. However, when such emergency circumstances arise the preferred method of financing government expenditures is through taxation and not borrowing. Notes Smith:

The public expence, however, when defrayed in this manner [through taxation], no doubt hinders more or less the further accumulation of new capital; but it does not necessarily occasion the destruction of any actually existing capital [as a result of the reduction of saving]. When the public expence it is defrayed by funding, it is defrayed by the annual 
destruction of some capital which had before existed in the country; by the perversion of some portion of the annual produce which had before destined for the maintenance of productive labour, towards that of unproductive labour. (Wealth of Nations, p. 878)

The above passage implies that taxation decreases mainly the households' expenditures and only to a limited extent savings. Taxation, therefore, unlike public borrowing does not encroach upon existing saving. Consequently, the amount of money borrowed by the government crowds out an equal amount of private investment. Hence, the underlying idea is that for Smith and the classical economists in general, "an act of saving is at the same time an act of investment". In short, taxation interferes with new investment and thus with the accumulation of new capital leaving the existing productive capacity intact, the same is not true, however, with public borrowing which undermines the existing productive capacity by displacing savings from the "maintenance of productive labour" to unproductive and wasteful usages. Hence, some caution should be applied because most classical economists did not have a very precise idea of what is investment. Most of them, by investment they mean mainly the wage fund, that is, the amount of money put aside by entrepreneurs in order to employ labor and perhaps another much smaller sum which could be either in money form or materials in order to carry out the production process smoothly. Investment goods proper were not so much in their perspective as they are for modern economists. $^{1}$

David Ricardo shares Smith's views on the unproductive character of government expenditures and on the notion that their financing via public borrowing "consumes" the investible product, and, therefore, it becomes detrimental to society's capacity to accumulate wealth. Notes Ricardo:

[The system of borrowing] is a system which tends to make us less thrifty - to blind us to our real situation. If the expense of a war be 40 millions per annum, and the share which a man would have to contribute towards that annual expense were $100 l$., he would endeavour, on being at once called upon for this portion, to save speedily the $100 \mathrm{l}$. from his income. By the system of loans, he is called upon to pay only the interest of this $100 l$., or $5 l$. per annum, and considers that he does enough by saving this $5 l$. from his expenditure, and then deludes himself with the belief, that he is as rich as before. (Principles, p. 247)

\footnotetext{
${ }^{1}$ This issue appears for example in the Ricardo Malthus debates on commodity gluts (for a summary Tsoulfidis, 2010, ch, 6).
} 
A similar argument was formulated three years later in his article on the Funding System (1820) (Works IV), where Ricardo evaluates three ways of financing a war of an annual cost of 20.000.000l. First, through direct taxation of 20.000.000l; second, through a loan, where the government will pay annually a specified sum in perpetuity and in agreed interest rate; if for example the interest rate is 5\% and remains constant, then the annual sum will be $1.000 .000 l$; third with a loan which will be paid in a specific time interval. If, for example, the interest rate is $5 \%$ and remains constant, then the annual payments of taxes will be counterbalanced with $1.000 .000 \mathrm{l}$ plus a sum; for example with $200.000 \mathrm{l}$ for the settlement of loan, whose maturity date is calculated to 45 years. From these three ways of financing, Ricardo argues that the first is preferred over the others (Works $I V$, p. 186).

Ricardo further explains the two methods of financing (taxation vs. borrowing) "in point of economy, there is no real difference" and this has been taken, by some economists, literally to mean the economic effects of the mode of financing are equal. Buchanan (1976) has coined the term "Ricardian Equivalence Theorem" and attributed it to Barro (1974), whose argument is that the policy of cutting taxation through the issue of bonds in the effort to raise aggregate demand cannot but fail, because the public anticipates the future increase in taxation for the payment of interest on the public debt and thus consumption expenditures fall. As a consequence, the final effects of deficit spending are similar regardless of the mode of financing. This argument lends support to the idea of ineffectiveness of government policies and became particularly popular in the 1980s. However, on further examination of Ricardo's text it becomes abundantly clear that the "equivalence" refers only to the collection cost and not to the economic effects of the two alternative methods of financing of government expenditures (see also O'Driscoll, 1977). ${ }^{2}$ First, because with taxation people are less willing to engage in an expensive and lasting war and second public borrowing means consumption of savings, and therefore slow down in capital accumulation (Works $I V$, p. 186). ${ }^{3}$ In the exceptional case, when the public deficit is financed through taxation it may produce in the short-run, the same results with those that would be caused from public borrowing. Ricardo argues that in the long run, the ruinous results of public borrowing in society's capacity to accumulate are even worse than those caused by taxation. The rationale is similar to Smith's, that

\footnotetext{
${ }^{2}$ For Ricardo's views on public debt see also see Churchman (2001) and Dome (2004).

${ }^{3}$ Smith also makes similar points (Wealth of Nations, p.878)
} 
is, borrowing doubtless "consumes" available savings, while the incidence of taxation is on current incomes for which we do not really know whether they were to be invested or consumed. In a letter to McCouloch (3/29/1820) Ricardo reiterates his views on public debt under the most difficult circumstances to defend them and these are in the case of war financing. He notes:

But when we are carrying on an expensive war and I is necessary to raise large funds within the year, either by loan, or by taxes equal in amount to such loan the former will I think be most injurious to the labourer, because it will more materially affect the accumulation of capital. (Works VIII, p. 170)

The reason is that in case of taxation, the consumption expenditures (especially of the rich consumers) will fall for one year in order to pay for the tax but the next year(s) the economy is expected to return to normality.

One could argue that Ricardo does not take into account the inter-generational effects of public debt and that the current generation given its limited time, perhaps, may not care so much about the tax, since what will pay at the end will be less than what they are called to pay once and for all. However, Ricardo explains that the economic unit of his analysis should include the household and not just the individual and by doing so, Ricardo makes the household an institution with infinite life time (since the income and the assets in general are transferred to the next generation as bequests) and thus his initial assumption about the difference in the method of financing still holds (Works $I V$, pp. 186-7).

\section{J.S. Mill and his Conjecture}

J.S. Mill argued along similar lines with Smith and Ricardo with regards to the alternative methods of financing of public expenditures. In fact, J.S. Mill qualified his view by arguing that public debt might be beneficial for a country, when it is financed from excess foreign savings, also when government borrowing generates savings that would otherwise have not taken place and finally when government borrowing absorbs domestic savings that would be either invested unproductively or invested in foreign countries. For example, in the case of unproductive government expenditures, he notes:

[...] if the capital taken in loans is abstracted from funds either engaged in production, or destined to be employed in it, their diversion from that purpose is equivalent to taking the amount from the wages of the labouring classes. (J.S. Mill, 1845, p. 230) 
Moreover, J.S. Mill (1845, p. 231) argued that insofar as loans absorb the investible product and under normal circumstance offset partially or wholly the falling tendency in the interest rate. In the unusual case of wars when the government urgently needs to finance its expenditures, as for example, was the case in the wars with France (1793-1815) the interest rates may increase. This increase in the interest rate, J.S. Mill argued constitutes prima facie evidence that the government is in direct competition against the private sector for funds that were destined to be invested productively (or rather in the private sector) and the state with the power of its authority diverts these funds to finance its unproductive activities. Notes J.S. Mill:

When they do raise the rate of interest, as they did in a most extraordinary degree during the French war, this is positive proof that the government is a competitor for capital with the ordinary channels, of productive investment, and is carrying off, not merely funds which would not, but funds which would, have found productive employment within the country. (J.S. Mill, 1845, p. 232)

Also J.S. Mill takes stock of the argument that the increase in the interest rate is caused by the increase of the rate of profit, and he argues that the causa causans of all the variables is the exceptionally rising public debt which by decreasing the private capital leads to a two-front competition: the firsts against private capital over liquid funds and this is manifested directly in the increase in the interest rate and the second of workers against workers over employment positions which reduces the real wage (or, more precisely, the wage fund) which is equivalent to saying that the economy's rate of profit is increased.

If it be objected that interest only rose because profits rose, I reply that this does not weaken, but strengthens, the argument. If the government loans produced the rise of profits by the great amount of capital which they absorbed, by what means can they have had this effect, unless by lowering the wages of labour? (J.S. Mill, 1845, p. 232)

Having established the theoretical relationships among the four variables, that is, public debt, interest rate, profit rate and real wage, J.S. Mill essentially identified the necessary variables of the classical model of public debt which is ready to be submitted to empirical testing. Given the availability of data, the most suitable period for testing the hypothesis of the classical economists is the one that starts with the Seven-Years War (1756-1763), continues with the War of the American Independence (1775-1783) and of course the fifteen years Wars with France that were 
carried out in two phases: the first from 1793 up to 1801 and the second from 1803 until 1815. Consequently, starting from the year 1756 and ending in the year $1815 \mathrm{a}$ period of six decades the time span is sufficiently long to study the economic consequences of the war-induced public debt on the relevant variables.

There is no doubt that this time period of sixty years the public debt increased to unprecedented highs and this has been well documented in the empirical literature. More specifically, Mitchell (1988) finds that the ratio of public debt to GDP in the UK rose from $137 \%$ in 1759 to $197 \%$ in 1801 and it was maintained approximately in this level until 1811, while in 1821 it was ejected to $288 \%$. Barro $(1989$, p. 238) gives more conservative estimates of the public debt to GDP ratio, according to which it was at the $90 \%$ in 1750 and increased to $140 \%$ in 1764 , it fell to $100 \%$ in 1775 and increased to $130 \%$ ten years later and to $160 \%$ in 1816 . More recently, Camen and Rogoff (2011) in their study of the evolution of Debt to GDP ratio for a number of countries, their findings with respect to the debt to GDP ratio for the UK economy are similar to those of Mitchel and Barro with the difference that the actual size of the ratio lies somewhere between the findings of the two studies.

Despite considerable differences, the three data sets convey approximately the same picture with regard to the rising tendency of the ratio of debt to GDP. These figures further suggest that the relative size of public debt for the UK was much larger compared to today's standards and that the concerns of the classical economists about the negative consequences of rising debt on economic growth can be submitted to test. Although the available data on the UK economy during the investigated period are less than accurate, nevertheless their visual inspection reveals their corroboration with the classical (J.S. Mill's) hypothesis for the economic effects of public debt. One could cast doubt to J.S. Mill's hypothesis by arguing that profits were high during the Napoleonic Wars not because of public debt, but because of the rapid progress in industrialization. However, J.S. Mill's counterargument would be that the progress in industrialization would have been even faster had the government not absorbed the domestic savings during the war and that these savings had been invested productively. Figure 1, below portrays the evolution of the variables of interest. Thus we display the debt-to-GDP ratio, the interest-rate on consols, which is a real interest rate as the price of consols encapsulates the effects of inflation, the evolution of the rate of profit and finally the real wage. 

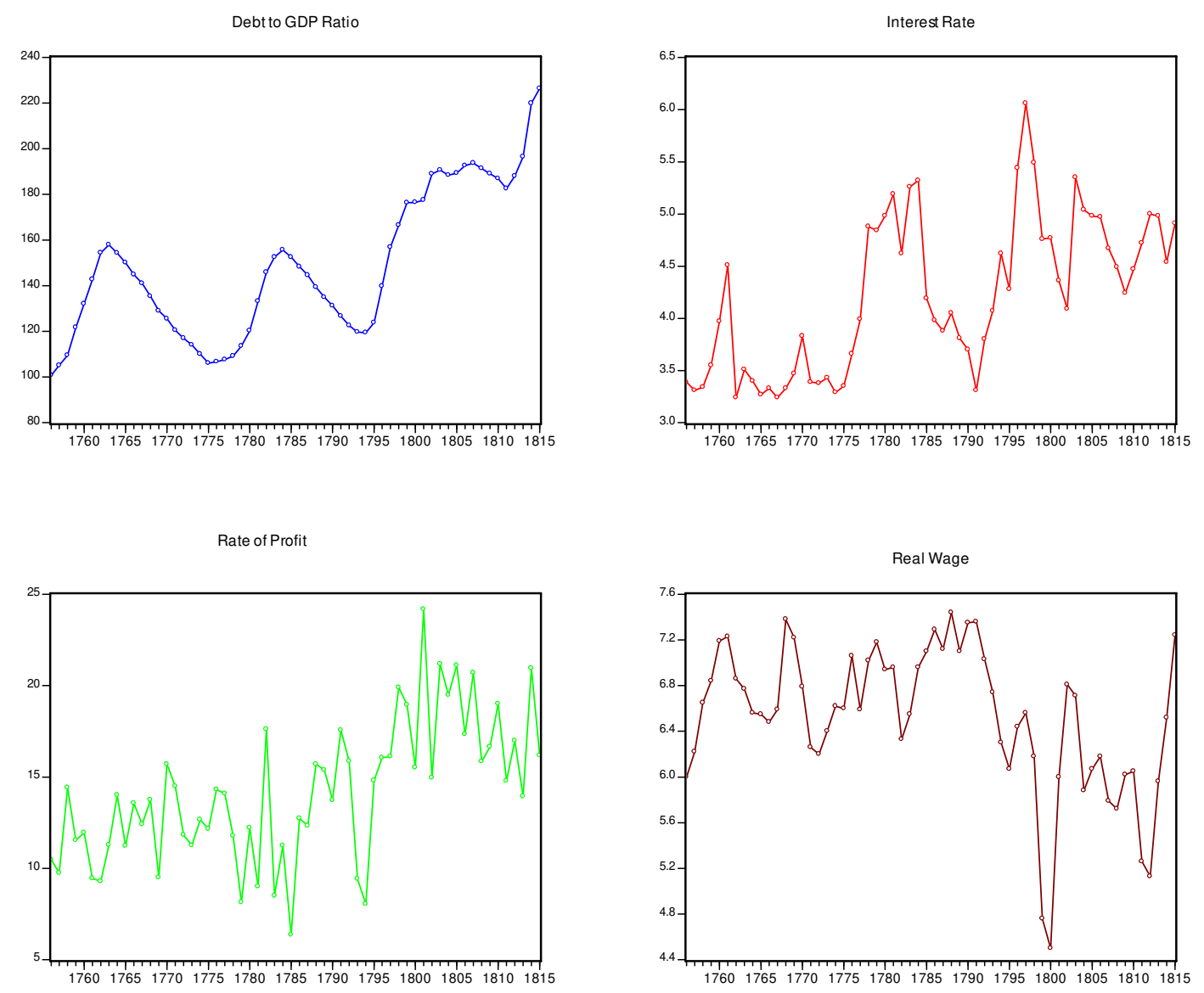

Figure 1. The Evolution of Debt to GDP ratio, Rate of Profit, Interest Rate and Wages in UK, $1756-1815^{4}$

The relationships among the variables are portrayed in Figure 2 below, where in the scatter graphs the debt to GDP ratio is positioned against each of the other three variables, that is, the rate of interest, the rate of profit and the real wage in the UK economy over the wars-infested period 1756-1815. We observe that there is a positive relationship between the debt to GDP ratio with the interest rate, the rate of profit and an inverse relationship with the wage rate. These relationships are portrayed in Figure 2 below; where we also draw the trend lines of the variables which all display the expected from J.S. Mill's conjecture behavior.

\footnotetext{
${ }^{4}$ The source of our data on public debt is Camen and Rogoff (2011), the real wage and interest rate on consols is from Makridakis et al. (1998), while the data on the rate of profit come from Mirowski (1982).
} 


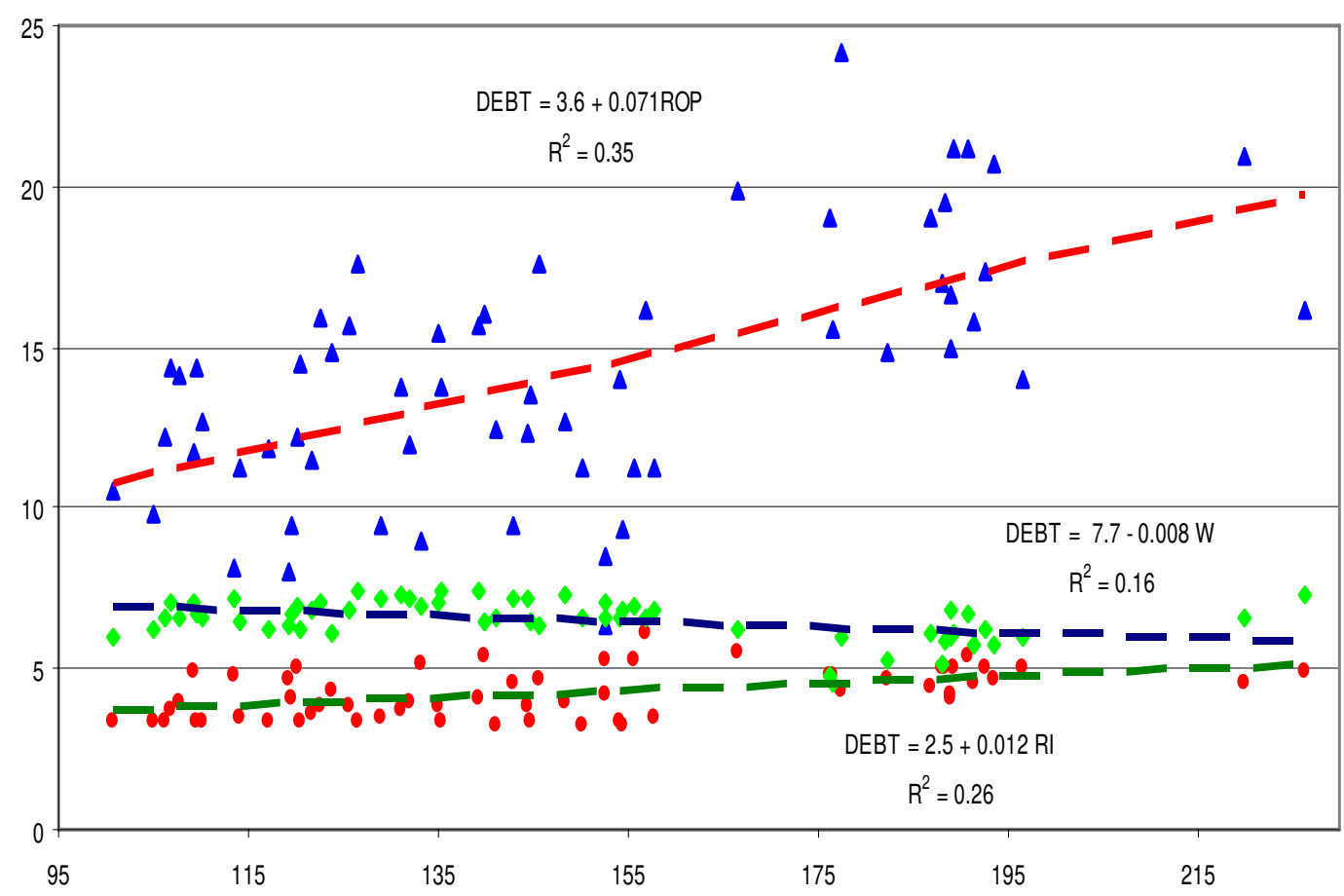

Figure 2. Debt to GDP ratio vs. interest-rate, rate of profit and real wage in the UK, 1756-1815.

The correlation coefficients of the involved variables are displayed in Table 1 below. The signs of these correlations are those expected from the classical hypothesis and the t-statistics (in parenthesis) of the coefficients show that the strength of association of the variables at hand is statistically significant.

Table 1. Correlation Matrix of Debt to GDP ratio, rate of profit, interest rate and real wages in UK, 1756-1815

\begin{tabular}{|c|c|c|c|c|}
\hline & Debt to GDP & Interest Rate & Rate of Profit & Real Wage \\
\hline Debt to GDP & 1 & & & \\
\hline Interest Rate & $0.511(4.7)$ & 1 & & \\
\hline Rate of Profit & $0.593(4.8)$ & $0.323(2.17)$ & 1 & \\
\hline Real Wage & $-0.400(3.2)$ & $-0.281(2.28)$ & $-0.394(3.1)$ & 1 \\
\hline
\end{tabular}

Overall, we can say that the available time series data, during the period under investigation, are consistent with J.S. Mill's conjecture. Of course, such data were not available to J.S. Mill; however, it is certain that classical economists had a powerful intuitive sense of the evolution of these variables. We observe that although the relationships between the variables are not very tight - the maximum correlation 
coefficient is 59.3 percent and the minimum 28.1 percent - nevertheless, given the complexity of the issue at had, we can attest that they are tight enough to lend reasonable support to J.S. Mill's and in general the classical hypothesis. Thus, by inspecting the correlation coefficients of Table 1 above, we find that the real wage and the rate of profit are inversely related and so is the real wage with the rate of interest, while the correlation of the profit rate with that of the interest rate is positive, exactly as anticipated by J.S. Mill.

\section{Concluding Remarks}

Summing up, classical economists (mainly Smith, Ricardo and J.S. Mill) share the view that countries should not run deficits and accumulate debt because of its pernicious effects on capital accumulation. Starting from the idea that savings are identical to investment it follows that public borrowing encroaches directly upon savings; that is, the income ready to be invested productively. Since government is, in general, unproductive, then public borrowing amounts to undermining of the economy's capacity to accumulate. If government expenditures are necessary, as in the case of a war, then the preferred way of financing them is through taxation and only exceptionally through borrowing. This view was expressed with great clarity by Smith and Ricardo and it was further elaborated by J.S. Mill, who described the precise causal relationships among the four variables at hand, i.e. the rising public debt, the rate of interest, the real wage and the rate of profit. The available data of the period 1956-1815 lend support to the theoretical analysis and intuition of J.S. Mill and by extension of Ricardo and Smith. These initial findings encourage further research within the theoretical framework of classical analysis and to its possible extension to current global economic predicament.

\section{References}

Barro, R. (1974) Are Government Bonds Net Wealth? Journal of Political Economy, 82(6), pp. 1095-1117.

Barro, R. (1989) The Ricardian Approach to Budget Deficits, Journal of Economic Perespectives 2:37-54.

Buchanan, J., (1976) Barro on the Ricardian Equivalence Theorem, Journal of Political Economy, 4(2), pp. 337-42.

Camen, R. and Rogoff, K. (2011) From Financial Crash to Debt Crisis, American Economic Review, 101 (August): 1676-1706

Churchman, N. (2001) David Ricardo on Public Debt. Basingstoke: Palgrave. 
Dome, T. (2004) The Political Economy of Public Finance in Britain, 1767-1873. London: Routledge.

Makridakis, S., Wheelwright, S. and Hyndman, R. (1998). Real Daily Wages in Pounds, England, 1260 - 1994. http://robjhyndman.com/forecasting/data/

Mill, J.S. (1848) Principles of Political Economy. Fairfield, NJ: Augustus M. Kelley, 1976.

Mirowski, P. (1982) Adam Smith Empiricism and the Rate of Profit in Eighteenth Century England, History of Political Economy, 14:2 pp. 179-198.

Mitchell, B. (1988) British Historical Statistics. Cambridge: Cambridge University Press.

O' Driscoll, G. (1977). The Ricardian Nonequivalence Theorem, Journal of Political Economy, 85(1), pp. 207-10.

Ricardo D. (1951a). On the Principles of Political Economy and Taxation, ed. by Sraffa, P. with the collaboration of M. Dobb, The Works and Correspondence of David Ricardo, vol. I, Cambridge: Cambridge University Press

Ricardo D. (1951b). The Works and Correspondence of David Ricardo, vol. IV, ed. by Sraffa, P. with the collaboration of M. Dobb, Cambridge: Cambridge University Press

Ricardo D. (1951c). The Works and Correspondence of David Ricardo, vol. IX, ed. by Sraffa, P. with the collaboration of M. Dobb. Cambridge: Cambridge University Press

Smith, A. (1776). The Wealth of Nations, edited by E. Cannan. New York: Random. House 1937.

Tsoulfidis, L. (2010) Competing Schools of Economic Thought. Heidelberg: Springer Verlag. 